\title{
7: 75087684-75085765
}

National Cancer Institute

\section{Source}

National Cancer Institute. 7: 75087684-75085765. NCI Thesaurus. Code C41869.

Physical location of CCL24_Gene 